DOI: $10.17803 / 2313-5395 \cdot 2021.1 .15 .085-098$

\title{
Bioethical Aspects of Human Rights in Modern Latin America
}

\author{
Juan Antonio Travieso, Angelo Viglianisi Ferraro, \\ Elena N. Trikoz, Elena E. Gulyaeva
}

Superior Council of the International Institute of Human Rights (IIDHAmérica) Department of Public Law at the University of Buenos Aires; Buenos Aires, Argentina

"Mediterranea" University of Reggio Calabria; Reggio Calabria, Italy

MGIMO University, Peoples Friendship University of Russia (RUDN

University),

Diplomatic Academy of the Russian Ministry of Foreign Affairs; Moscow, Russia

Abstract: The aim of the paper is to analyze the bioethical aspects of the institution of human rights in Latin America. The result of the present research is the author's conclusion on the necessity of the practical implementation of legal provisions in this area, and their judicial enforcement in many states of Latin America with the aim of compliance with international standards of human rights. In the face of global uncertainty of COVID-19, it is more necessary than ever to maintain a strong commitment to international law and human rights with responsibility in bioethics, and also to seek to preserve and consolidate what has been advanced in the construction of a world order based on rules and shared values, along with a policy structured on common values and international principles. States must take international responsibility for wrongful acts for the violation of human rights in biolaw. The research methodology was based on general scientific and private scientific methods of cognition (the dialectical method, methods of analysis and synthesis, deduction and induction, comparative legal and historical legal methods). The biolaw basing on the International Law and Human Rights has its special understanding of the issue, which should be supported by further legislative development in Latin America. Latin American courts will not be able to make judgments on bioethical issues for a long time, while it is closely related to biopolitics and other controversial regional political positions. There are structural and historical problems of Latin American legal culture, a high index 
of criminal impunity and wide discretion of law-enforcement agencies that do not apply specific principles of biolaw and even bypass official bioethical guidelines in their practice. The author's give overview of the practice of Mexico on the matter of the legislative process in biolaw. The paper focuses on different theoretical approaches.

Keywords: Bioethics, biopolitics, biomedical technologies, biolaw, genetics, human rights, justice, patient rights, legal culture, COVID-19

Cite as: Travieso, J.A., Ferraro, A.V., Trikoz, E.N. and Gulyaeva, E.E., (2021). Bioethical Aspects of Human Rights in Modern Latin America. Kutafin Law Review, 8(1), pp. 85-98, doi: 10.17803/23135395.2021.1.15.085-098

\section{Contents}

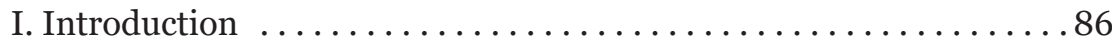

II. The Complex Latin American Model of Bioethics ........... 87

III. Can Bioethics Show a Better Future in Latin America?... . . . . . 92

IV. Conclusion ............................... 95

References .................................

\section{Introduction}

Law, just like social sciences and arts, is always observing the world and people. It is not a simple observation. It is a complex vision through social sciences, arts, and law altogether. This vision is not just complex, it is stereoscopic and scattered like a light reflected by a prism (Cárdenas Quiroga et al., 2015).

The vision sometimes gets transformed because the light or perspective is constantly changing. This is what happens when we look at ourselves in mirrors and the key thing is the image it reflects or the riddle it gives. Although sometimes the best vision of us is through the eyes of our friends. But the issue is that law and all other disciplines are guidelines, which, when synchronized, allow us to evaluate various things around. That is why, by looking at bioethics, we place ourselves in the company of lawyers who come along with us on this trip.

Currently, bioethics is a rapidly developing interdisciplinary sphere in Latin America. Being a special branch of science and practical 
activity, bioethics differs from biopolitics (Denisenko and Trikoz, 2020). But bioethics is still not much influential in the Latin American region from the academic point of view. On the whole, bioethical programs are supported only in big cities and only in some countries (ÁlvarezDíaz, 2012).

The Black Swan of COVID-19 unexpectedly changed the whole perception of the facts (Malinovsky, Osina and Trikoz, 2021). Recently, The New York Times published the statistics of people killed by COVID-19 and the statistics of the unemployed in the US. The optimism was ruined by reality, as usual.

That is the reason why sometimes lawyers seem bureaucratized intellectuals who are far from the reality that motivates us. The idea that we have in mind is the urgent need for the law to have done what must be done in the fight for bioethics as well as to combat climate change and other contemporary challenges. We know that it is a voice crying in the wilderness of existing rules.

According to the National Commission of Bioethics in Mexico (La Comisión Nacional de Bioética - CONBIOÉTICA), 'bioethics is a branch of applied ethics, which reflects, examines, and applies normative and socio-political approaches to managing and resolving conflicts in social life, especially in life sciences, medical practice, and medical studies, which affect life on the planet both now and in the future'.

This definition of bioethics is typical of the Latin American region and it stems from the necessity to develop a conceptual approach since a generally accepted definition of bioethics has not been framed yet. The term bioethics was introduced almost a hundred years ago. In 1927, Fritz Jahr defined bioethics as the ethics of the way people deal with animals and nature. But it was Van Rensselaer Potter who brought the term into the modern scientific discourse in his article Bioethics, the Science of Survival (1970).

\section{The Complex Latin American Model of Bioethics}

Bearing in mind that the law is in a position to take responsibility for human well-being, let us see how the combination of international law and human rights can operate in the contemporary world where 
forests are burning, the pandemic is booming, and many conflicts remain unsolved.

First, it is difficult to synthesize the objective expressions of international law and human rights as well as their conceptual frameworks. Anyway, we are going to see whether the previous problems and concerns will dissipate, for example, smoke after fires or ill health after vaccinations.

All the events that frame international crises, generally with serious violations of human rights, make us address to other disciplines, which are related to jurisprudence. Bioethics is understood as a branch of ethics dedicated to promoting the principles for the most appropriate conduct of human beings with respect to human life and the life of other living beings as well as the environment with acceptable conditions to make all these achievements possible.

Nowadays, bioethics is 'an ongoing interdisciplinary life science dialogue through the lenses of human values aimed to frame, express, and probably solve a number of problems, arising in the process of laboratory research, intervention in human life, environment, and the Earth's biosphere'. This detailed definition is used by the Regional Office of Bioethics under the Pan American Health Organization (Santiago de Chile). In legal discourse, bioethics implies a philosophical, moral, and ethical evaluation of medico-biological procedures, studies, treatment methods, genetic engineering technologies, organ transplantations, caring for terminally ill people, etc. (Stepke, 2010). In the Latin American region, bioethics is regarded in close relationship with the tools for human rights protection, promotion of democracy, and civic engagement. It results in a more politicized concept of bioethics (Cossio, 2013).

According to Vila-Coro Barrachina, it is possible to distinguish three types of bioethics, depending on the way it is applied: a) conceptual (theoretical) bioethics or 'meta-bioethics' as a science; b) cultural bioethics, aimed to raise new bioethical dilemmas in historical and socio-

${ }^{1}$ Selecciones de Bioética No 15 del Instituto de Bioética de la Pontificia Universidad Javeriana de Colombia. Archivado desde el original el 5 de junio de 2016. 
cultural contexts; c) clinical bioethics (medical deontology), proposing ethical solutions for the problems, which arise in the professional treatment of patients; d) normative bioethics (biolaw) (Garcia et al., 2019; Trikoz, 2020), embracing healthcare rules of law, which come from lawyers and public authorities (Vila-Coro Barrachina, 2010).

In 1979, Tom L. Beauchamp and James F. Childress published the book Principles of Biomedical Ethics. The book has become a doctrinal landmark. It is still commonly cited because it contains arguments for the classical triad of bioethical principles: beneficence, nonmaleficence, autonomy, and justice. These principles are closely related to the concepts of respect for human dignity, human rights and autonomy protection, tolerance, inclusiveness, solidarity, and nondiscrimination. These are the guidelines for the practical application of bioethics in the Latin American context. ${ }^{2}$

Inequality is an undeniable fact in Latin America. This fact is underlying two bioethical premises - the pursuit of justice and protection for everybody. A special historical context of Latin American bioethics builds on the regional cultures and their links to Anglo-Saxon, Portuguese, Spanish, and Mediterranean traditions. In the beginning, it was a combustible combination of the despotic ethics, typical of colonial conquest times, and the paternalistic ethics of the colonial domination and caste system. But paternalistic treatment in medicine and bioethics never reached the lowest level of the Latin American caste system (Guerra, 1972). In the modern era, the development of Latin American bioethics resulted in ethnical independence and bioethical sovereignty with new principles: the institutionalization of local bioethics committees; informed consent; autonomy of the patient; consultations on ethical and legal issues; obligatory prenatal diagnostic tests; availability of reproductive technologies; bioethics of cell, tissue, and organ transplantations; controlled genomic experiments, etc. Nevertheless, three main goals of bioethical studies have not been achieved yet: education and enlightenment, public health, and political influence (Mainetti, 1998).

${ }^{2}$ ¿Qué es Bioética? Available at: http://www.conbioetica-mexico.salud.gob.mx/ interior/queeslabioetica.html [Accessed 24.01.2021]. 
Alfonso L. Escobar notes that culturally and technologically Latin American countries are not yet ready for the humanization of advanced biotechnologies because they are still strongly influenced by catholic ethics, conservative Hippocratian tradition, and paternalistic ideology (Escobar, 2010). An opposite opinion is put forward in another expert publication by Edmundo Estévez and Agustín García. It is a work on ethical and legal issues of future medicine, human genome studies, the right to abortion, the rights of unborn children, ethical treatment of animals, etc. (Estévez and García, 2009). ${ }^{3}$

Currently, Latin American legislative initiatives and studies of relationships among bioethics, theology, medicine, and law are booming. This fact is within the overall trends of bioethics. The urge in bioethical studies was facilitated by FELAIBE, the Regional Program on Bioethics under the Pan American Health Organization, the Center of Bioethics at the San Paolo Bolivian Catholic University, the Latin American and Caribbean Congress of REDBIOÉTICA, and Human Genome Meeting in Cancún (Mexico). In 2010, an international conference, organized by UNESCO in Mexico City, brought together the representatives of Latin American bioethics bodies and the European Commission. They met to share experiences in fulfilling national obligations, including obligations on the Universal Declaration on Bioethics and Human Rights of $2005 .^{4}$

Recently, the problems of the legal status of unborn children and the protection of an embryo's rights have become topical in the region. The Western European legal tradition is very influential in this area. It sets the framework for regulation by analogy with the solution of the issue, provided by the rules of the biolaws and case law of the European Union (Gulyaeva and Trikoz, 2018; 2020). The trend is facilitated by the rapid development of modern molecular genetic diagnostics methods in the

${ }^{3}$ Latin American and Caribbean Federation of Institutions of Bioethics (Federación Latinoamericana y del Caribe de Instituciones de Bioética). Available at: http://www.felaibe.org [Accessed 24.01.2021]; REDBIOÉTICA has its own Web portal, with an Analysis Department based in Buenos Aires, (www.redbioeticaunesco.org) and the online publication of REDBIOÉTICA UNESCO Journal [Accessed 24.01.2021].

4 Bioethics Committees reached an agreement on their work in Mexico. UNESCO Social and Human Sciences Sector magazine. January-March 2010. 3. 
EU and North America. One of the topics of the 6th Framework Program on EU Research was about the ethical and legal considerations on the possibility of a) carrying out scientific research on human embryos on national territories; b) carrying out scientific research on stem cells derived from human embryos after the 6th Framework Program on EU Research is launched; c) producing stem cells by deriving them from human embryos.

The European Parliament expressed its opinions in three principal resolutions: the first resolution (1989) on genetic engineering invites all the Member States to forbid, by virtue of specific legislative provisions, any gene transfer to human germ line cells; the second provision (1989) on artificial insemination both in vitro and in vivo is particularly rigorous about research activities on embryos; the third resolution (1997) concerns a total ban on human beings cloning. In 1998, the European Group on Ethics and Science in New Technologies decided to deprive research projects, which resulted in the destruction of human embryos, of community funding.

Among the Member States, there is an agreed consensus on when scientific research on embryos is allowed. The ECHR Member States are entitled to exercise broad discretion in terms of enacting the legal regime to be applied to the donation of embryos..$^{5}$ Embryos are protected under the laws of other legal systems of the European Union (Pardinini, 2004). Every human being shall have the right to life and human dignity; the life of a fetus shall be protected from the moment of conception (Vincze and Varju, 2012). For example, in Italy, interventions are permissible only to guarantee the embryo's integrity and for its recovery, avoiding disproportionate risks. Indeed, carrying out scientific research on an embryo is a complex issue (especially when evaluating the potential risk of its destruction). The Law on Medically Assisted Procreation of 2004 not by chance emphasizes the 'right of the conceived to a certain identity as well as to a non-manipulated genetic heritage'. But the Law simplifies the issue related to the destiny of supernumerary embryos by highlighting that 'the issue shall not be addressed through a general law on medically assisted procreation'.

${ }^{5}$ para. 183 of the Parrillo decision. ECHR 27 August 2015, Parrillo v. Italy. 
More Latin American laboratories are adopting the methods of reproductive medicine genetic diagnoses: pre-implantation genetic diagnosis and prenatal testing. Some Latin American countries still do not have any legal prohibitions or restrictions on such diagnoses. That is why it is up to the managers of private clinics and genetic research labs to decide how much this or that procedure is appropriate and ethical. Moreover, there are problems with independent licensing and legal regulation of these activities. There are not so many well-prepared certified geneticists. Human dignity can, beyond its ontological and constitutional value, constitute a legal limit for scientific manipulations with human embryos in accordance with moral principles and respect for human life.

\section{Can Bioethics Show a Better Future in Latin America?}

The truth is that bioethics is now responding to the 21st century crisis of the techno-scientific era. This crisis is both vital and normative. It is about threatened life and broken morality. They provoke three main factors: the environmental catastrophe, the biological revolution, and the medicalization of culture. As Mainetti (1998) asserts, there has been a shift in cultural paradigms.

In the same way, bioethics, i.e. the paradigm of techno-scientific ethics, provides us with a technological imperative according to which everything that can be done must be done. Halfway between the apocalyptic forecasts and messianic prophecies of techno-science, there is the third facet of the universal bioethical paradigm, which affirms humanism and proclaims the principles of autonomy, beneficence, freedom, and well-being of a moral and reasonable person.

Thus, the light at the end of the tunnel seems to be a way out but along the way, we will have to go through the succession of symbolic tunnels. These are the tunnels of reproductive ethics, which requires analyzing the issues of contraception, sterilization, and abortion alongside with studying the relationships between life expectancy and the quality of life. Mainetti also touches upon a complex morality of 
assisted reproduction that provokes so far, a peaceful controversy between Catholics and secularists. The need for legal regulation on the matter is becoming more urgent every day. The same is also true for thanatological ethics, the ethics of death, the ethics of research, and the ethics of health.

Environmental ethics must also be taken into account (Malinovsky, Osina and Trikoz, 2020). Perhaps bioethics will be a new chapter in the book of human rights for the next millennium. Bioethics will become a part of the new rights because if development consists of health, wellbeing, and progress, health is going to mean the quality of life and progress is going to mean sustainable development.

We are planning what bioethics should be at the time of COVID-19, feeling a big discomfort, which requires insisting on the ethics of the common good and just society. It is a kind of macro ethics, which aims at the consolidation of civil and political rights as well as making economic, social, and cultural rights available to everybody.

It seems that the tunnels lead us to the Socratic classicism. Borges and Socrates are lighting the way out of the mirrors and the tunnels. The door opens for us to ponder ethics, history, and human rights framed in a new law. We should not use the words escape or exit. In Latin, the word exitus also meant success, result, or end. A very common phrase was incerto exitu victoriae - the result of the victory is uncertain. Thus, the word success probably matches the situation well.

In Latin American countries, all human rights are developing but actually only one human right is possible - the one that ensures the dignity of people.

In the early 2000s, Latin American countries started a new cycle of the legal regulation of bioethics, clinical practices, and genetic studies (Bulle Goyri, 2013). In Brazil and later in some other countries, the right to a decent standard of living and access to medical care was fixed constitutionally. In the context of bioethics, this right is regarded as a universal right of working people (Garrafa, Rocha da Cunha and Manchola, 2018).

Mexico has established a National Commission on Bioethics (CONBIOÉTICA), which has become the main centralized body of the 
Health Ministry. CONBIOÉTICA is a technically and organizationally autonomous unit. It is responsible for setting up national policy and legislative proposals in the field of bioethics. It supported the adoption of the Mexican Healthcare Law of 2009 and the Agreement by Consejo de Salubridad General of 2014, which established a program to improve the life of terminally ill patients (Hall, Campos Pacheco and Pérez Audiffred, n.d.). The Mexican Bill of Rights of Patients, first introduced in Parliament in 2001, is being debated for over 20 years. There is a proposal to fix a patient's right to consent to treatment or refuse from it. CONBIOÉTICA emphasizes that very often medical practitioners are not aware of a patient's right to refuse from treatment. That is why doctors seldom discuss treatment options with their patients and this fact contradicts the bioethical principle of informed consent (Camino and Hall, 2020). Under the Criminal Code of the Mexican state of Querétaro, a doctor who has violated ethical principles in medicine can be sentenced up to three years of imprisonment. ${ }^{6}$ Another Mexican state of Tabasco has a Law on Assistive Reproductive Methods, which adds contractual surrogacy rules to the Civil Code of the state (Camino and Hall, 2020).

It should be noted that the Ethics Code, applicable to the Mexican federal public servants, contains the principles, which the public servants must follow. Among them, there is a principle of equality and non-discrimination. The public servants are working for everybody without any exception, i.e. regardless of an ethnic or national origin, skin color, culture, sex, age, or disability; social, economical, medical, or legal status; pregnancy, language, belief, sexual orientation, personal or political preferences; marital status, criminal record, or any other reason. ${ }^{7}$ This provision meets modern international standards in the

${ }^{6}$ Poder Legislativo del Estado de Queretaro (2009) Codigo Penal para el Estado de Querétaro, Article 243. LVIII Legislatura Queretaro. Direccion de Investigacion y Estadistica Legislativa. Available at: http://legislaturaqueretaro.gob.mx/app/ uploads/2016/01/CODo04.pdf [Accessed 24.01.2021].

7 Código de Ética de los Servidores Públicos del Gobierno Federal [Accessed 24.01.2021]. 
sphere of human rights at the time of the fourth industrial revolution. On the whole, Mexican law is an example of a well-developed legislation on the issues of bioethics, genome studies, and other aspects of the emerging branch of biolaw.

\section{Conclusion}

Indeed, the humanism of the 2oth century, which people used as the measure of all things and an epistemological basis, can no longer be adapted to the new information societies, which are rather speedy, scientific, and technological.

To escape from that standard, it is necessary to pass a law that would make people do what needs to be done while fighting for the survival of the planet. The author of Sapiens: a Brief History of Humankind and Homo Deus: A Brief History of Tomorrow affirms that now we have three enemies that threaten all humans. Their threats should make us work together. These enemies are nuclear war, climate change, and technological disruption. All of these are global enemies, which cannot be defeated by any particular nation. We recognize the existence of transnational actors but in this situation, it is necessary to work much and consolidate the efforts of both international agreements and international organizations. They should operate in a transparent and active network, protecting human rights. The other alternative consists of perceiving history in its entirety and striving to unravel the mechanisms of the future, with an accurate determination about the destiny of international law and human rights in the context of bioethics.

In the face of global uncertainty, it is more necessary than ever to maintain a strong commitment to international law and human rights, covered with responsible bioethics. At the same time, there are serious problems that can hinder legal provisions on bioethics from practical implementation. For instance, J.R. Cossio, an ex-justice of the Mexican Supreme Court, cited the case, challenging the law that decriminalized abortions in Mexico City. He believes that Latin American courts will not be able to pass landmark judgments on bioethical issues until they are bound by biopolitics and other controversial political positions (Cossio, 2013). 
Mexico shares this trend with many Latin American countries. It happens due to many factors, including structural and historically entrenched problems of the Latin American legal culture, e.g. the high level of criminal impunity and wide discretion in law enforcement. As a result, specific principles of the biolaw and official bioethical recommendations are easy to circumvent.

\section{References}

1. Álvarez-Díaz, J.A., (2012). Bioética latinoamericana o bioética en Latinoamérica [Latin American bioethics or bioethics in Latin America]. Revista Latinoamericana de Bioética, 1, pp. 10-27.

2. Bulle Goyri, V.M., (2013). Bioética, Derecho y Derechos Humanos. Perspectivas de Bioética. Mexico.

3. Camino, B.G. and Hall, R.T., (2020). Bioethics and the Law in Mexico. Rev Bio y Der, 49, pp. 107-123.

4. Cárdenas Quiroga, E.A., Morales Martín, L.Y. and Ussa Caycedo. A., (2015). La estereoscopía, métodos y aplicaciones en diferentes áreas del conocimiento. Rev. Cient. Gen. José María Córdova, 13(16), pp. 201-219.

5. Cossio, J.R., (2013). Derecho y Bioética. In: González Valenzuela J. (ed). Perspectivas de Bioética. Mexico: University Nacional Autónoma de Mexico.

6. Cossio, J.R., (2013). Derecho y Bioética. Perspectivas de Bioética. Mexico: University Nacional Autónoma de Mexico, Comisión Nacional de los Derechos Humanos and Fondo de Cultura Económica.

7. Denisenko, V. and Trikoz, E., (2020). Biopolitics and legal issues of emergencies in the context of coronavirus pandemic. E3S Web of Conferences, 175(14013), pp. 1-7, doi: https://doi.org/10.1051/e3sconf/202017514013. (In Russ.).

8. Escobar, A.L., (2010). Bioethics in Latin America and Colombia. In: IberoAmerican Bioethics: History and Perspectives. Springer Science.

9. Estévez, E., and García, A., (2009). Bioética de intervención. Los derechos humanos y la dignidad humana. Quito: Textos de enseñanza universitaria.

10. Garcia, L.F., Fernandes, M.S., Moreno, J.D. and Goldim, J.R., (2019). Mapping Bioethics in Latin America: History, Theoretical Models, and Scientific Output. Journal of Bioethical Inquiry, 16(3), pp. 323-331.

11. Garrafa, V., Rocha da Cunha, T. and Manchola, C., (2018). Access to Healthcare: A Central Question within Brazilian Bioethics. Cambridge Quarterly of Healthcare Ethics, 27(03), pp. 431-439.

12. Guerra, F., (1972). Medicina colonial en Hispanoamerica. In: Entralgo, P. Lain (ed). Historia universal de la medicina. Salvat, Barcelona.

13. Gulyaeva, E.E. and Trikoz, E.N., (2020). Legal Aspects of Bioethics and Genomics in Latin America. Aktualnye problemy sravnitelnogo prava, 1, pp. 4249. (In Russ.). 
14. Hall, R.T., Campos Pacheco, E.G. and Pérez Audiffred, A.P., (n.d.). Cuidado paliativo: Bioética y la ley lo que opinaron los medicos. Newsletter, Gaceta of the National Bioethics Commission CONBIOETICA. Gaceta VI (25), pp. 14-20.

15. Halliday, S.A., (2004). Comparative Approach to the Regulation of Human Embryonic Stem Cell Research in Europe. Medical Law Review, 12, pp. 40-43.

16. Mainetti, A., (1998). Bioethics in Latin America. In: Reich W. (ed). Encyclopedia of bioethics. London.

17. Malinovsky, A., Osina, D. and Trikoz, E., (2020). Legal Instruments for Stimulating Environmentally Friendly Behavior: Successful Practices in Russia and Abroad. E3S Web of Conferences, 164(11039), pp. 1-11. (In Russ.).

18. Malinovsky, A.A., Osina, D.M. and Trikoz, E.N., (2021). State Support for the Russian Economy Affected by COVID-19 Consequences (Legal Aspects). In: Ashmarina, S., Mantulenko, V. and Vochozka, M. (eds). Engineering Economics: Decisions and Solutions from Eurasian Perspective, 139 Engineering Economics Week 2020. Lecture Notes in Networks and Systems, pp. 283-287, doi: https://doi. org/10.1007/978-3-030-53277-2_33. (In Russ.).

19. Pardini, C., (2016). Libertà di ricerca scientifica e tutela dell'embrione. Nuova Giurisprudenza Civile Commentata.

20. Stepke, F.L., (2010). The Pan American Health Organization and Latin American Bioethics. In: Pessini, L., Barchifontaine, Ch.P. de and Stepke, F.L. (eds). Ibero-American Bioethics: History and Perspectives. Springer Science+ Business Media B.V.

21. Trikoz, E.N. and Gulyaeva, E.E., (2018). ECHR Positions on Certain Issues of Bioethics and Genetic Data, Advances in Law Studies. Scientific and Theoretic Journal, 6(4), pp. 36-40. (In Russ.).

22. Trikoz, E.N., (2020). Communicative Function of Biolaw Development.

In: Legal Communication between State and Society: Domestic and Foreign Experience. Voronezh. (In Russ.).

23. Vila-Coro Barrachina, M.D., (2010). La vida humana en la encrucijada. Pensar la bioética. Madrid: Ediciones Encuentro.

24. Vincze, A., Varju, M., (2012). Hungary. The New Fundamental Law. European public law, p. 444.

\section{Information about the authors}

Juan Antonio Travieso, Ph.D., President of the Superior Council of the International Institute of Human Rights (IIDH-América); Director of the Department of Public Law at the University of Buenos Aires (Argentina); Founder and first Director of the National Directorate of Personal Data Protection of the Ministry of Justice of Argentina

Viamonte 430, C1053 CABA, Argentina

jatravieso@gmail.com 
Angelo Viglianisi Ferraro, Ph.D. (Civil Law), Aggregate Professor of European Private Law and the Erasmus Coordinator at the Department of Law, Economics and Human Science of the "Mediterranea" University of Reggio Calabria; Director of the "Mediterranea International Centre for Human Rights Research" (Italy)

Via dell'Università, 25, 89124 Reggio Calabria RC, Italy

avf@unirc.it

Elena N. Trikoz, Cand. Sci. (Law), Associate Professor, International Law Department, MGIMO University

Prospekt Vernadskogo, 76, Moscow, Russia, 119454

Peoples Friendship University of Russia (RUDN University)

Miklukho-Maklaya St., 6, Moscow, Russia, 117198

alena_trikoz@mail.ru

Elena E. Gulyaeva, Cand. Sci. (Law), Member of the Council for International Relations of the International Institute of Human Rights (IIDH-America); European Law Department, Diplomatic Academy of the Russian Ministry of Foreign Affairs

Ostozhenka St., 53/2-1, Moscow, Russia

gulya-eva@yandex.ru 